\section{Efek Ekstrak Kasar Cacing Tanah Pheretima sp. terhadap Morfologi Sel Bakteri Salmonella enteritidis}

\author{
Sahribulan \\ Dirayah Rauf H \\ Zohra Hasyim
}

\begin{abstract}
Abstrak. Penelitian ini bertujuan untuk mengetahui perubahan morfologi sel bakteri Salmonella enteritidis setelah pemberian ekstrak kasar cacing tanah Pheretima $s p$. dengan menggunakan mikroskop pemindai elektron /scanning electron microscope (SEM). Ekstraksi cacing tanah menggunakan pelarut etanol 96\%, dan diperlakukan pada kultur bakteri yang berada pada fase eksponensial dengan konsentrasi ekstrak 5\% dan 10\%. Pengamatan dengan menggunakan pemindai mikroskop elektron dilakukan setelah penambahan ekstrak yang berjangka 6 jam, 12 jam, dan 24 jam. Diperoleh hasil yang menunjukkan adanya pengaruh ekstrak kasar cacing tanah Pheretima $s p$. terhadap perubahan morfologi sel bakteri Salmonella enteritidis. Sel bakteri Salmonella enteritidis mengalami kerusakan berupa: terbentuk lubang pada permukaan sel bakteri, tonjolantonjolan pada permukaan sel bakteri, pengerutan sel bakteri, pemanjangan sel bakteri, dan terjadinya lisis sel bakteri. Selain itu diamati pula bahwa konsentrasi dan semakin lama waktu inkubasi setelah penambahan ekstrak kasar cacing tanah Pheretima sp. terhadap bakteri Salmonella enteritidis, maka semakin besar pula kerusakan yang ditimbulkan. Namun konsentrasi ekstrak 5\% sudah merupakan konsentrasi yang optimum dalam menimbulkan kerusakan terhadap morfologi sel bakteri Salmonella enteritidis.
\end{abstract}

Kata kunci: Ekstrak Kasar, Cacing Tanah, Pheretima sp., Morfologi Sel, Salmonella enteritidis, Scanning Electron Microscope (SEM).

\section{Pendahuluan}

Antimikroba adalah zat yang mampu menekan pertumbuhan dan reproduksi mikroba atau mampu membunuh mikroba (Syahrurachman, 1994). Antimikroba dapat pula diartikan sebagai bahan atau suatu komponen kimia yang memiliki kemampuan dalam menghambat pertumbuhan dan perkembangan mikroba (Darkuni, 2001). Menurut Pelczar dan Chan (1986) antimikroba merupakan suatu zat yang digunakan untuk mengendalikan mikroba, baik dalam menghambat pertumbuhan, membasmi atau membunuh mikroba. Sampai saat ini, antimikroba masih merupakan salah satu obat yang paling sering digunakan untuk mengobati penyakit yang disebabkan oleh bakteri patogen. Cacing tanah dari familia Lumbricidae dapat di bedakan atas genus Lumbricus, Eisenia, Pheretima, Perionyx, Diplocardi, dan Lidrillus. Cacing tanah mempunyai potensi yang sangat besar bagi kehidupan dan kesejahteraan manusia. Beberapa jenis cacing tanah yang berasal dari galur lokal yang telah banyak diternakkan adalah yang bersal dari genus Lumbricus, Pheretima dan Pherionyx (Dudung, 2008). Penelitian Marthur et al. (2010) juga membandingkan bioaktivitas ekstrak etanol dan ekstrak

\section{BIONATURE}

\author{
p-ISSN 1411 - 4720 \\ e-ISSN 2654 - 5160
}

Abtract. This study was aimed at studying changes in the morphology of Salmonella enteritidis bacterial cells after the crude extract of Pheretima sp. using a scanning electron microscope (SEM). Earthworm extraction uses $96 \%$ ethanol, and binds to the appropriate bacteria in the exponential phase with extract concentrations of $5 \%$ and $10 \%$.

Observations using a microscope scanner were carried out after agreeing to a 6-hour, 12-hour, and 24-hour extract. Obtained from the results showing the crude extract of Pheretima

sp. to changes in cell morphology of Salmonella enteritidis bacteria. Salmonella enteritidis bacterial cells are damaged consisting of: formed holes in the surface of bacterial cells, bumps on the surface of bacterial cells, shrinkage of bacterial cells, elongation of bacterial cells, and increase in bacterial cells. In addition, as well as longer contributions and free time, incubation, after being added, crude extract of Pheretima sp. against Salmonella enteritidis bacteria, the greater the damage caused. However, $5 \%$ extract concentration is the optimal concentration in the effect

of damage to the morphology of the cells of Salmonella enteritidis bacteria. Keywords: Coarse Extract, Earthworms, Pheretima sp. Morphological Cells, Salmonella enteritidis, Scanning Electron Microscope (SEM).

Sahribulan

Universitas Negeri Makassar Indonesia

Dirayah Rauf H

Universitas Hasanuddin Makassar Indonesia

Zohra Hasyim

Universitas Hasanuddin Makassar Indonesia 
petroleum eter dari cacing tanah Eudrillus eugeniae. Didapatkan bahwa ekstrak etanol lebih besar daya hambatnya yakni $18 \mathrm{~mm}$ terhadap bakteri Staphylococcus aureus dan $15 \mathrm{~mm}$ terhadap bakteri Escherichia coli dibanding ekstrak petroleum eter masing-masing sebesar 15 $\mathrm{mm}$ dan $10 \mathrm{~mm}$.

Para ahli menemukan bahwa cairan selom dari cacing tanah mengandung lebih dari 40 protein, dengan beberapa aktivitas biologis diantaranya: citolitik, proteolitik, antimikroba, hemolitik, tumorolitik, kegiatan mitogenik Selanjutnya Affandi dan Muliasari (1996) dalam Aydogdu dan Aysin telah membuktikan bahwa adanya daya antibakteri dari protein hasil ekstraksi cacing tanah Lumbricus rubellus dan Pheretima sp. yang dapat menghambat pertumbuhan bakteri Gram negatif Escherichia coli, Shigella dysenteriae, Staphylococcusaureus dan Salmonella typhi.

Serangkaian penelitian tentang pemanfaatan potensi cacing tanah dalam memproduksi antibiotik telah banyak diketahui, namun pemanfaatan dari cacing tanah jenis Pheretima $s p$. masih kurang dimanfaatkan. Seperti penelitian yang telah dilakukan Rahmawati (2010) ditemukan bahwa senyawa bioaktif yang terdapat pada ekstrak kasar dan semua fraksi protein cacing tanah Pheretima sp. bersifat cenderung menghambat pertumbuhan bakteri dalam jangka waktu yang tidak lama atau disebut bersifat bakteriostatik.

Berdasarkan uraian di atas, maka akan dilakukan penelitian untuk mengamati perubahan morfologi bakteri Salmonella enteritidis setelah pemberian antibakteri yang berasal dari ekstrak cacing Pheretima sp. dengan harapan hasil penelitian ini dapat memberi informasi dalam upaya pencarian senyawa yang memiliki sifat farmakologi yang berasal dari alam sehingga dapat dimanfaatkan untuk kehidupan masyarakat.

\section{Metode Penelitian}

\section{Bahan penelitian}

Bahan yang akan digunakan dalam penelitian ini adalah cacing tanah Pheretima sp., biakan bakteri Salmonella typhi, Salmonella enteritidis, kertas saring, etanol, ektrak daging, pepton, agar, akuades, alkohol 50\%, alkohol 70\%, alkohol 85\%, alkohol 95\% dan alkohol absolut, larutan gutaraldehyd 2,5\%, larutan tanin acid 2\%, larutan caccodylate buffer $0,2 \mathrm{M}$, larutan osmium tetraoksida 0,25\%, larutan t-butanol, aluminium foil, tissu, dan korek api.

\section{Cara Kerja}

\section{Penyiapan Sampel}

Cacing yang diambil adalah yang telah dewasa yang ditandai dengan adanya klitellum yang menebal dan warnanya lebih terang dari warna tubuhnya. Sampel cacing Pheretima sp. yang telah kering dihaluskan dengan blender sehingga diperoleh tepung cacing dan siap untuk proses selanjutnya.

\section{Maserasi dan Ekstraksi}

Ekstraksi bahan dilakukan secara maserasi dengan menggunakan pelarut etanol $96 \%$ Pa. Bahan berupa tepung cacing tanah Pheretima sp. sebanyak 500-gram dimaserasi dengan pelarut etanol dan dibiarkan selama 1x24 jam ditempat yang terlindung dari cahaya pada suhu kamar, sambil berulang-ulang diaduk. Bahan disaring menggunakan corong Buchner dan ekstraknya ditampung. Ampas kemudian direndam kembali dengan pelarut etanol untuk dimaserasi seperti tahap pertama. Proses ini berlangsung sampai 3 kali maserasi. Ekstrak yang diperoleh digabungkan dan ditentukan volumenya. Ekstrak etanol cair yang diperoleh dievaporasi dan kemudian ditimbang. 


\section{Pengukuran Pertumbuhan Bakteri Uji}

Kultur bakteri yang telah diinokulasi dalam 150 ml nutrient broth (NB) kemudian diambil sebanyak $5 \mathrm{ml}$ lalu dimasukkan ke dalam tabung dan diukur nilai optical dencity (OD) sebagai $\mathrm{T}_{0}$ pada panjang gelombang $610 \mathrm{~nm}$ dengan menggunakan spektrofotometer, kemudian kultur yang lain di inkubasi pada incubator bergoyang (shaker) dengan kecepatan 100 $\mathrm{rpm} /$ menit pada suhu $37^{\circ} \mathrm{C}$. Selanjutnya diukur kembali nilai optical dencity (OD) tiap interval waktu 3 jam sebagai nilai $\mathrm{T}_{1}$ sampai $\mathrm{T}_{\mathrm{n}}$. Nilai-nilai yang di peroleh kemudian dimasukkan kedalam table yang selanjutnya akan dibuatkan kurva pertumbuhannya.

\section{Preparasi Sampel Untuk Pengamatan Morfologi Sel Bakteri Uji Pada Pemindai Mikroskop Elektron}

Metode yang digunakan dalam analiasa kerusakan morfologi sel bakteri uji pada mikroskop pemindai elektron berdasarkan metode yang di lakukan oleh Belguith, et al. 2009 dan Noor, 2001. Pengerjaan preparasi sampel akan didampingi oleh teknisi dari laboratorium.

1. Disiapkan isolat bakteri uji yang telah diremajakan dalam agar miring.

2. Kemudian diambil 1 ose isolat bakteri uji dan diinkubasi dalam nutrient broth selama 24 jam.

3. Kultur bakteri uji yang telah diinkubasi, dimasukkan ke dalam 7 buah tabung reaksi yaitu 6 tabung reaksi yang akan ditambahkan dengan ekstrak kasar cacing tanah Pheretima sp. 3 tabung untuk kosentrasi $5 \%\left(\mathrm{R}_{1 \mathrm{a}}, \mathrm{R}_{2 \mathrm{a}}, \mathrm{R}_{3 \mathrm{a}}\right), 3$ tabung untuk konsentrasi $10 \%\left(\mathrm{R}_{1 \mathrm{~b}}, \mathrm{R}_{2 \mathrm{~b}}, \mathrm{R}_{3 \mathrm{~b}}\right)$ dan 1 tabung reaksi sebagai kontrol, masing-masing sebanyak 1 ml kultur bakteri uji.

4. Kultur bakteri uji tersebut kemudian ditambahkan dengan ekstrak kasar cacing tanah Pheretima sp. masing-masing sebnyak $1 \mathrm{ml}$ ke dalam tabung reaksi, 3 tabung untuk kosentrasi 5\% ( $\left.\mathrm{R}_{1 \mathrm{a}}, \mathrm{R}_{2 \mathrm{a}}, \mathrm{R}_{3 \mathrm{a}}\right), 3$ tabung untuk konsentrasi $10 \%\left(\mathrm{R}_{1 \mathrm{~b}}, \mathrm{R}_{2 \mathrm{~b}}, \mathrm{R}_{3 \mathrm{~b}}\right)$ kemudian diinkubasi pada suhu $37^{\circ} \mathrm{C}$ bersama dengan kultur bakteri kontrol.

5. Bakteri uji dalam tabung reaksi $R_{1 a}$ dan $R_{1 b}$ diamati pada masa inkubasi selama 6 jam, $R_{2 a}$ dan $\mathrm{R}_{2 \mathrm{~b}}$ diamati pada masa $12 \mathrm{jam}, \mathrm{R}_{3 \mathrm{a}}$ dan $\mathrm{R}_{3 \mathrm{~b}}$ diamati pada masa inkubasi $24 \mathrm{jam}$.

6. Untuk kosentrasi $5 \%\left(\mathrm{R}_{1 \mathrm{a}}, \mathrm{R}_{2 \mathrm{a}}, \mathrm{R}_{3 \mathrm{a}}\right)$, untuk konsentrasi $10 \%\left(\mathrm{R}_{1 \mathrm{~b}}, \mathrm{R}_{2 \mathrm{~b}}, \mathrm{R}_{3 \mathrm{~b}}\right)$, dan kontrol dari bakteri uji kemudian di fiksasi untuk persiapan pengamatan pada pemindai mikroskop elektron (SEM) dengan menambahkan 0,5 ml larutan glutaraldehyde 2,5\% sebagai larutan fiksatif lalu dibiarkan selama 2 jam pada suhu $4^{\circ} \mathrm{C}$. Penambahan larutan glutaraldehyde berfungsi untuk menjaga bentuk bakteri agar tetap utuh.

7. Selanjutnya bakteri uji yang telah ditambahkan glutaraldehyde $2,5 \%$ kemudian disentrifus dengan kecepatan $1550 \mathrm{rpm}$ selama 10 menit, larutan fiksatif (glutaraldehyde) dibuang, endapan bakteri ditambahkan $1 \mathrm{ml}$ larutan fiksatif tanin acid 2\%, kemudian dibiarkan selama 1 x 24 jam pada suhu $4^{\circ} \mathrm{C}$.

8. Selanjutnya bakteri uji yang telah ditambahkan larutan fiksatif tanin acid $2 \%$ kemudian disentrifus kembali dengan kecepatan 1550 rpm selama 10 menit larutan fiksatif (tanin acid) dibuang, endapan bakteri ditambahkan 1 ml larutan caccodylate buffer dibiarkan selama 10 menit pada suhu $4^{\circ} \mathrm{C}$ (dilakukan sebanyak 2 kali).

9. Selanjutnya bakteri yang telah ditambahkan caccodylate buffer disentrifus kembali dengan kecepatan 1550 rpm selama 10 menit, larutan buffer dibuang endapan bakteri ditambahkan $1 \mathrm{ml}$ larutan osmium tetraoksida 1\% selanjutnya dihomogenkan, dan dibiarkan selama 60 menit pada suhu $4^{\circ} \mathrm{C}$. Penambahan larutan osmium tetraoksida berfungsi untuk melapisi bakteri agar bersifat konduktif.

10. Selanjutnya bakteri yang telah ditambahkan osmium tetraoksida $1 \%$ disentrifus kembali dengan kecepatan 1550 rpm selama 10 menit, larutan osmium tetraoksida dibuang, endapan bakteri kemudian di tambahkan $1 \mathrm{ml}$ alkohol 50\%, direndam 10 menit (hal tersebut dilakukan $2 \mathrm{x}$ ) 
11. Selanjutnya berturut-turut ditambahkan dengan $1 \mathrm{ml}$ alkohol bertingkat $70 \%, 80 \%$, dan 95\% direndam masing-masing 10 menit, kemudian dengan alkohol absolute direndam selama 10 menit (dilakukan sebanya 2 kali), setiap pergantian konsentrasi alkohol sampel dengan kecepatan 1550 rpm selama 10 menit. Penambahan alkohol bertingkat berfungsi untuk dehidrasi sel bakteri.

12. Selanjutnya setelah penambahan alkohol absolut disentrifus kembali dengan kecepatan $1550 \mathrm{rpm}$ selama 10 menit, larutan dibuang, lalu ditambahkan $1 \mathrm{ml}$ larutan t-butanol, kemudian direndam selam 10 menit (dilakukan sebanyak 2 kali), dan dibuatkan suspensi tbutanol. Penambahan t-butanol berfungsi sebagai larutan untuk dehidrasi.

13. Suspensi dalam butanol kemudian di oles pada cover slip yang telah direkatkan pada stub alumunium, setelah itu suspensi yang telah mengering pada cover slip kemudian dilapisi dengan emas melalui proses vakum selama 20 menit.

14. Cover slip yang telah dilapisi dengan emas selanjutnya diamati menggunakan mikroskop pemindai elektron.

\section{Hasil dan Pembahasan}

\section{Ekstrak cacing tanah Pheretima sp.}

Penelitian ini menggunakan spesies cacing tanah Pheretima sp. yang diambil dari peternakan PT. Vermi Sakti Internasional Bandung, Jawa Barat. Ekstrasi cacing tanah Pheretima sp., menggunakan pelarut etanol 96\% Pa. Fungsi pelarut etanol yaitu untuk menarik senyawa semipolar yang bersifat antimikroba yang terkandung dalam tubuh cacing tanah Pheretima sp. Untuk memperoleh ekstrak kasar cacing tanah, sebanyak 500 g cacing tanah Pheretima $s p$ kering dihaluskan dengan menggunakan blander hingga berbentuk tepung seperti nampak pada Gambar 13. a. Tepung cacing tanah Pheretima $s p$ yang tersebut selanjutnya dimaserasi dengan pelarut etanol $96 \%$ sebanyak $700 \mathrm{ml}$. Perendaman dilakukan selama 1 x 24 dan diulangi sebanyak tiga kali maserasi. Selanjutnya dilakukan penyaringan untuk memisahkan antara maserat dan ampas dari cacing tanah Pheretima sp. dengan menggunakan corong Buchner. Hasil maserat kemudian dievaporasi sehingga diperoleh ekstrak kasar cacing tanah Pheretima $s p$. (ekstrak etanol) sebanyak 88, 4 g yang berwarna hitam seperti pada Gambar 13. b.

Senyawa yang bersifat sebagai antimikroba terkandung dalam ekstrak kasar cacing tanah diantaranya senyawa alkaloid, fenolik, flavanoid, tanin, terpenoid, steroid. Berdasarkan uji skrining fitokimia oleh Yuniati (2012) terhadap ekstrak kloroform cacing tanah Pheretima sp mendeteksi adanya kandungan senyawa berupa fenolik, terpenoid, steroid, alkaloid, dan flavonoid. Selain itu Sajuthi et al. (2009) dalam Yuniati (2012) mengemukakan bahwa cacing tanah Lumbricus rubellus dan Pheretima aspergillum memiliki senyawa aktif yang berpotensi sebagai antipiretik termasuk golongan alkaloid. Selain itu dalam Riset dan Teknologi (2011) mengatakan bahwa protein yang dimiliki oleh cacing tanah memiliki mekanisme antimikroba yang berbeda dengan mekanisme antibiotik. Mekanisme yang dilakukan oleh protein yang dimiliki oleh cacing tanah adalah dengan membuat pori di dinding sel bakteri. Hal ini menyebakan sitoplasma sel bakteri menjadi terpapar dengan lingkungan luar yang dapat mengganggu aktivitas dalam sel bakteri dan menyebabkan kematian. Dengan cara ini, bakteri menjadi lebih susah untuk menjadi resisten karena yang dirusak adalah struktur sel milik bakteri itu sendiri. 


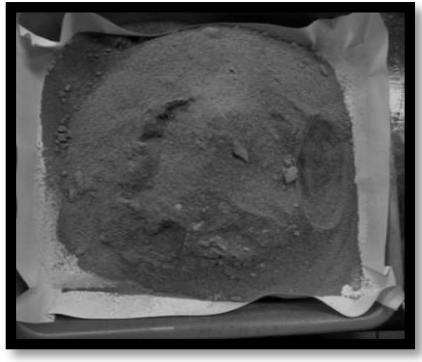

(a)

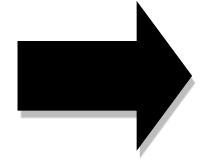

(b)

Gambar 1. Tepung Cacing Tanah Pheretima sp. (a), Hasil Ekstrak Kasar Cacing tanah Pheretima sp. (b)

\section{Pengukuran Kurva Pertumbuhan Bakteri Salmonella typhi}

Bakteri Salmonella typhi yang sedianya digunakan dalam penelitian ini sebagai bakteri uji, diukur pertumbuhannya untuk dibuatkan kurva pertumbuhannya. Tujuan dari pembuatan kurva pertumbuhan bakteri uji tersebut yaitu untuk mengetahui bahwa pada fase pertumbuhan mana dilakukan pemberian antimikroba. Hal tersebut dimaksudkan untuk mengetahui fase optimal dalam mempengaruhi sel bakteri yang akan diujikan dengan ekstrak cacint tanah Pheretima sp.

Pengukuran pertumbuhan bakteri Salmonella typhi dalam penelitian ini dilakukan dengan menggunakan spektrofotometer pada panjang gelombang $610 \mathrm{~nm}$. Pengukuran tersebut dilakukan untuk memperoleh nilai optical density/absorban. Pengukuran pertumbuhan bakteri Salmonella typhi dilakukan setiap interval waktu 2 jam. Nilai optical density/absorban yang diperoleh selanjutnya dimasukkan ke dalam tabel yang akan diplot pada kertas grafik semi logaritma.

Tabel 1. Hasil Pengukuran Nilai Optical Density (OD)/Nilai Absorban dari Pertumbuhan Bakteri Salmonella typhi

\begin{tabular}{|c|c|c|}
\hline No & $\begin{array}{c}\text { Waktu } \\
\text { (Jam) }\end{array}$ & $\begin{array}{c}\text { Nilai Optical } \\
\text { Density (OD)/Absorban }\end{array}$ \\
\hline T0 & 0 & 0,012 \\
\hline T1 & 2 & 0,520 \\
\hline T2 & 4 & 0,776 \\
\hline T3 & 6 & 0,761 \\
\hline T4 & 8 & 0,781 \\
\hline T5 & 10 & 0,820 \\
\hline T6 & 12 & 0,829 \\
\hline T7 & 14 & 0,858 \\
\hline T8 & 16 & 1,051 \\
\hline T9 & 18 & 1,261 \\
\hline T10 & 20 & 1,127 \\
\hline T11 & 22 & 1,322 \\
\hline T12 & 24 & 1,262 \\
\hline
\end{tabular}

\begin{tabular}{|c|c|c}
\hline No & $\begin{array}{c}\text { Waktu } \\
\text { (Jam) }\end{array}$ & $\begin{array}{c}\text { Nilai } \text { Optical } \\
\text { Density (OD)/Absorban }\end{array}$ \\
\hline T13 & 26 & 1,323 \\
\hline T14 & 28 & 1,381 \\
\hline T15 & 30 & 1,437 \\
\hline T16 & 32 & 1,456 \\
\hline T17 & 34 & 1,453 \\
\hline T18 & 36 & 1,483 \\
\hline T19 & 38 & 1,488 \\
\hline T20 & 40 & 1,421 \\
\hline T21 & 42 & 1,386 \\
\hline T22 & 44 & 1,332 \\
\hline & & \\
& & \\
& & \\
\end{tabular}


Nilai optical density/absorban yang telah diperoleh kemudian diplot diatas kertas grafik semi logaritma kemudian ditentukan fase pertumbuhan dari bakteri Salmonella typhi. Berdasarkan penelitian yang telah dilakukan diketahui bahwa, fase eksponensial dari pertumbuhan bakteri Salmonella typhi terletak antara 22-24 jam masa inkubasi dengan waktu generasi selama 7 jam. Masa inkubasi 24 jam diambil sebagai fase eksponensial. Pada masa inkubasi tersebut dilakukan penambahan ekstrak kasar cacing tanah Pheretima sp. untuk diuji seberapa besar efek yang ditimbulkan terhadap perubahan morfologi sel bakteri Salmonella typhi dalam berbagai variasi waktu inkubasi. Berikut merupakan grafik kurva pertumbuhan dari bakteri Salmonella typhi.

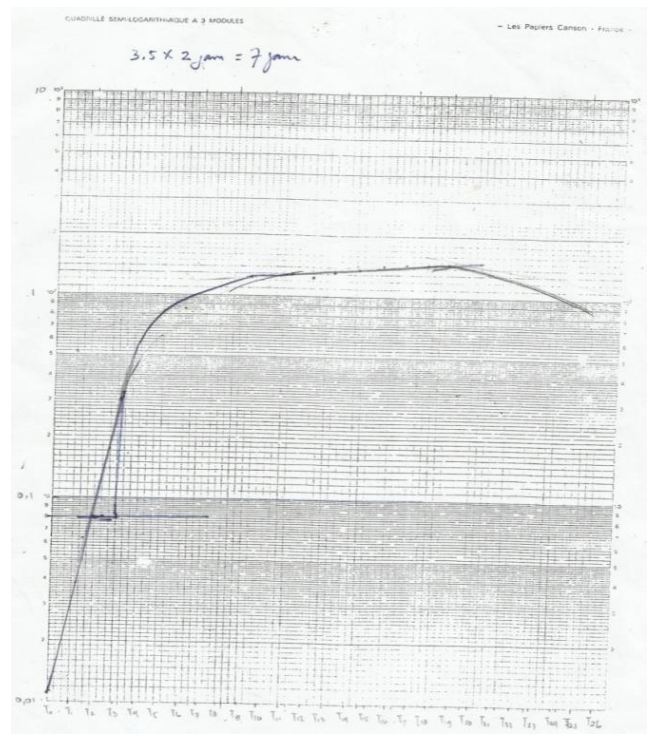

\section{Gambar 2. Foto Hasil Kurva Pertumbuhan Bakteri Salmonella typhi}

\section{Pengamatan Morfologi Sel Bakteri Uji pada Mikroskop Pemindai Elektron}

Pengujian aktivitas antibakteri ekstrak kasar cacing tanah Phetrima sp. menggunakan konsentrasi 5\% dan 10\%. Masing-masing konsentrasi diinkubasi selama 6 jam,12 jam dan 24 jam. Hasil penelitian ini menunjukkan adanya aktivitas antibakteri ekstrak kasar cacing tanah Pheretima sp. terhadap bakteri Salmonella enteritidis. Ekstrak kasar cacing tanah Phetrima $s p$. memberikan pengaruh yang signifikan terhadap morfologi sel bakteri Salmonella enteritidis. Pengaruh terhadap morfologi sel bakteri yang diamati dengan mengguanakan mikroskop pemindai elektron secara umum nampak berupa tonjolan-tonjolan pada permukaan sel, terjadi kebocoran sel, pengelupasan sel, pengkerutan sel, pemanjangan sel, dan lisis sel. Namun perubahan yang terjadi pada morfologi sel bakteri Salmonella enteritidis bervariasi antara konsentrasi dan masa inkubasi yang diberikan. Perbedaan tersebut akan dijelaskan sebagai berikut.

\section{Perlakuan ekstrak kasar cacing tanah Phetrima sp. pada konsentrasi 5\% terhadap Bakteri Salmonella enteritidis}

Berdasarkan pengamatan yang telah dilakukan dengan menggunakan mikroskop pemindai elektron tipe JSM-5310 LV terlihat bahwa pemberian ekstrak kasar cacing tanah Pheretima sp. pada konsentrasi 5\% menyebabkan terjadinya perubahan perubahan/kerusakan morfologi bakteri Salmonella enteritidis. Sel bakteri Salmonella enteritidis yang normal 
(kontrol) berbentuk batang utuh dan permukaannya halus nampak pada Gambar 15. a. Perlakuan sampel pada konsentrasi 5\% dengan masa inkubasi 6 jam nampak pada Gambar 15. b, terlihat adanya tonjolan-tonjolan pada permukaan sel bakteri Salmonella enteritidis. Menurut Gilbert (1984) dalam Miksusanti et al. (2008) terbentuknya tonjolan-tonjolan kecil pada sel bakteri disebabkan oleh ketidakmampuan peptidoglikan sel yang rusak. Senyawa antibakteri menahan tekanan intraseluler yang tinggi, sehingga sitoplasma dan membran sitoplasma keluar. Tonjolan ini biasanya muncul pada daerah-daerah yang dilemahkan oleh senyawa antibakteri. Terbentuknya tonjolan ini merupakan tanda terganggunya proses biosintesis dinding sel bakteri.

Pada konsentrasi 5\% dengan masa inkubasi 12 jam terlihat pada Gambar 15. a. Nampak adanya lubang pada pada permukaan dinding sel bakteri Salmonella enteritidis. Kerusakan ini merupakan kerusakan akibat terganggunya sintesis dinding sel dan berubahnya permeabilitas sel dan pada akhirnya akan menyebabkan kerusakan yang lebih berat.

Pada konsentrasi 5\% dengan masa inkubasi 24 jam terlihat pada Gambar 15. d. Nampak bentuk sel bakteri Salmonella enteritidis mengalami pengkerutan. Demikian penelitian yang telah dilakukan oleh Asriani (2006) dalam Hasyim (2011) yaitu mekanisme antibakteri metabolit Lb. Planta num kik - MAG minyak kelapa terhadap Salmonella typhi. Menunjukkan bahwa senyawa antibakteri metabolit Lb. Plantanum kik - MAG minyak kelapa tersebut menyebabkan cairan sel bakteri merembes keluar karena terjadi lisis pada dinding sel. Keluarnya cairan sel dalam jumlah besar mngakibatkan terjadinya pengkerutan pada sel bakteri.
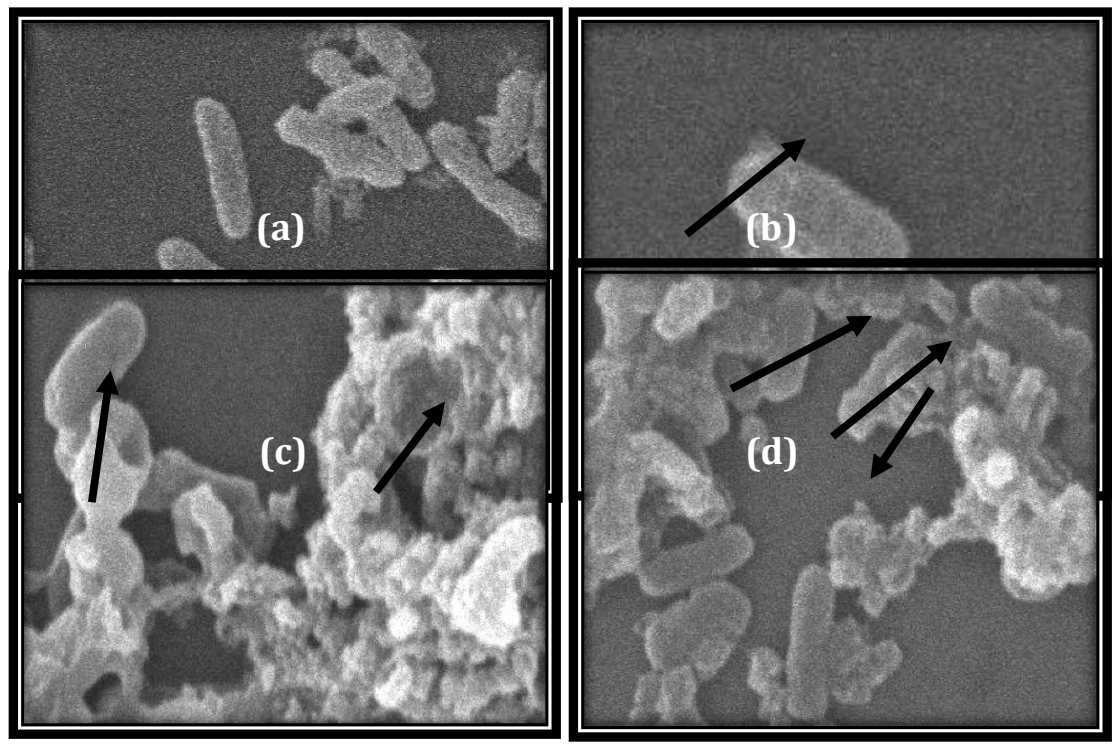

Gambar 3. Morfologi normal sel Salmonella enteritidis dan Morfologi yang Mengalami Kerusakan Setelah diberi Perlakuan Ekstrak Kasar Cacing Tanah Pheretima sp. konsentrasi 5\%

Keterangan: Morfologi normal sel Salmonella enteritidis (a); morfologi Salmonella enteritidis perlakuan ekstrak cacing tanah Pheretima sp. pada konsentrasi 5\% inkubasi 6 jam (b morfologi Salmonella enteritidis perlakuan ekstrak cacing tanah Pheretima $s p$. pada konsentrasi 5\% inkubasi 12 jam (c); morfologi Salmonella enteritidis perlakuan ekstrak cacing tanah Pheretima sp. pada konsentrasi 5\% inkubasi 24 jam (d). Pembesaran $10.000 \mathrm{X}$. 
Perlakuan ekstrak kasar cacing tanah Phetrima sp. pada konsentrasi 10\% terhadap Bakteri Salmonella enteritidis

Kerusakan morfologi bakteri uji terlihat pula pada pemberian ekstrak kasar cacing tanah Pheretima sp. pada konsentrasi 10\%. Sel bakteri Salmonella enteritidis yang normal (kontrol) berbentuk batang utuh dan permukaannya halus nampak pada Gambar 16. a.

Perlakuan sampel pada konsentrasi 10\% dengan masa inkubasi 6 jam telihat pada Gambar 16 . b. Nampak adanya tonjolan-tonjolan pada permukaan sel bakteri Salmonella enteritidis, dan ada pula sel bakteri Salmonella enteritidis yang mengkerut. Pada konsentrasi 10\% pada masa inkubasi 12 jam terlihat pada Gambar 16. c. Nampak sel bakteri juga mengalami pengkerutan dan cairan sel bakteri merembes keluar. Pada konsentrasi $10 \%$ pada masa inkubasi 24 jam terlihat pada Gambar 16. d. Sel bakteri Salmonella enteritidis juga mengalami pengkerutan dan cairan sel bakteri merembes keluar, bahkan terjadi lisis sel yang menyebabkan kehancuran pada sel bakteri.

Menurut McGuire dan Conrad (2000) dalam Miksusanti et al. (2008) bahwa sel yang mengalami kerusakan berat biasanya disebut sebagai ghost cell. Sel ghost ini biasanya hanya terdiri dari kulit bagian luar tapi tidak memiliki peptidoglikan. Terbentuknya sel ghost ini diduga karena terjadi gangguan terhadap sintesis dinding sel dan berubahnya permeabilitas sel yang akhirnya menyababkan terlepasnya material sel keluar. Penelitian yang serupa dilakukan oleh Suliantari (2009) yang menggunakan ekstrak sirih.
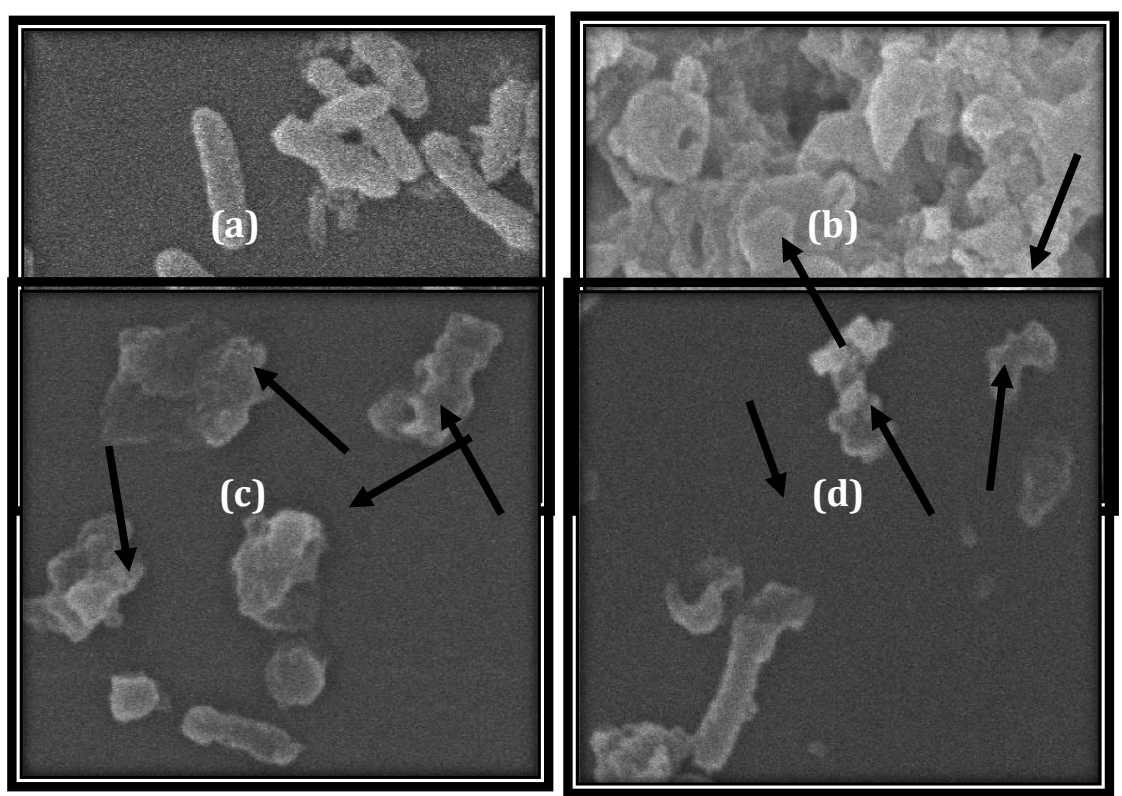

Gambar 4. Morfologi normal sel Salmonella enteritidis dan Morfologi yang Mengalami Kerusakan Setelah diberi Perlakuan Ekstrak Kasar Cacing Tanah Pheretima sp. konsentrasi $10 \%$

Keterangan: Morfologi normal sel Salmonella enteritidis (a); morfologi Salmonella enteritidis perlakuan ekstrak cacing tanah Pheretima sp. pada konsentrasi 10\% inkubasi 6 jam (b morfologi Salmonella enteritidis perlakuan ekstrak cacing tanah Pheretima $s p$. pada konsentrasi 10\% inkubasi 12 jam (c); morfologi Salmonella enteritidis perlakuan ekstrak cacing tanah Pheretima sp. pada konsentrasi 10\% inkubasi 24 jam (d). Pembesaran 10.000 X. 
Hasil pengamatan menunjukkan bahwa ekstrak cacing tanah Pheretima sp. konsentrasi 5\% dan 10\% sudah optimum dalam menimbulkan kerusakan terhadap morfologi sel bakteri Salmonella enteritidis. Namun kerusakan yang ditimbulkan oleh ekstrak cacing tanah Pheretima $s p$. konsentrasi $10 \%$ lebih besar dalam melakukan pengrusakan terhadap sel bakteri Salmonella enteritidis. Hal tersebut dapat diketahui dengan melihat kerusakan morfologi sel bakteri Salmonella enteritidis. Kerusakan yang ditimbulkan oleh ekstrak cacing tanah Pheretima $s p$. konsentrasi $10 \%$ lebih besar dibandingkan dengan konsentrasi 5\%. Disamping itu, masa inkubasi bakteri Salmonella enteritidis dalam ekstrak cacing tanah Pheretima sp. juga berpengaruh terhadap bentuk kerusakan yang terjadi. Masa inkubasi yang lebih lama yaitu 24 jam menunjukkan kerusakan yang lebih besar baik pada ekstrak cacing tanah Pheretima sp. konsentrasi $5 \%$ maupun pada konsentrasi $10 \%$.

Berdasarkan hasil penelitian ini dapat diketahui penyebab mengapa ekstrak kasar cacing tanah Pheretima sp. dapat mengahambat pertumbuhan beberapa bakteri yang telah diujikan. Hasil pengamatan menunjukkan adanya kerusakan yang terjadi pada sel bakteri Salmonella enteritidis. Kerusakan yang nampak antara lain terbentuknya lubang pada dinding sel, adanya tonjolan-tonjolan di permukaan sel, pengkerutan sel, patahan sel, hingga lisis sel. Kerusakan tersebut terjadi akibat dari mekanisme kerja dari senyawa antibakteri yang terkandung dalam ekstrak kasar cacing tanah Pheretima sp. Kerusakan tersebut membuktikan terganggunya sintesis dinding sel bakteri, fungsi membran sel bakteri, bahkan mungkin menyebabkan terganggunya metabolisme sel bakteri. Hal ini sejalan dengan mekanisme kerja dari antimikroba yang diungkapkan oleh Ganiswara, (1995) dan Lullmann et al. (2005) diantanranya penghambatan terhadap sintesis dinding sel, penghambatan terhadap fungsi membran sel, penghambatan sintesis protein, penghambatan sintesis asam nukleat dan penghambatan metabolisme sel. Tergangggunya aktivitas sel bakteri, dapat dipastikan akan mengganggu pertumbuhan sel bakteri, dengan kata lain dapat menghambat pertumbuhan sel bakteri.

Menurut Salzet et al. (2006) dalam Hasyim (2011) bawah salah satu protein yang dikandung oleh cacing tanah yaitu lizozim yang terbukti menghambat pertumbuhan bakteri gram positif. Selain itu, cairan soelomik yang dimiliki oleh filum Annelida juga bersifat sebagai antibakteri, hemolitik dan hemaglutinat.

Hasil penelitian yang dilakukan oleh Seok et al. dalam Suliantari (2009) bahwa bakteri Lactobacillus sp pada kondisi lingkungan yang sangat asam akan menyebabkan komponen utama dari membran sel bakteri tersebut mengalami kerusakan dan akibatnya komponenkomponen intraseluler seperti $\mathrm{Ca} 2+, \mathrm{Mg} 2+, \mathrm{K}+$ dan lipid akan dikeluarkan. Terjadinya pengeluaran Mg2+ dari sel Lactobacillus, plantarum pada kondisi asam mencirikan adanya kerusakan membran. Indikasi lain dari adanya kerusakan membran sitoplasma adalah terjadinya kebocoran ion $\mathrm{K}+$ dan peningkatan kandungan $\mathrm{K}+$ yang dilepaskan merupakan tanda kerusakan permeabilitas membran. Dari penelitian Cox et al. (2001) dalam Suliantari (2009) mengungkapkan bahwa komponen aktif dari teh akan menyebabkan kerusakan membran dan kebocoran ion K+ dari bakteri E. coli AG 100 dan S. aureus NCTC 8325. Kation Ca2+ dan Mg2+ terdapat pada bagian fosfolipid membran sel sehingga dengan adanya kerusakan membran maka ikatan kation tersebut akan rusak.

Pengaruh senyawa yang bersifat antimikroba terhadap sel bakteri dapat menyebabkan terjadinya kerusakan atau perubahan pada bentuk morfologi bahkan sifat fisiologi dari sel bakteri dan pada akhirnya akan menyebabkan kematian pada sel bakteri. Davidson dan Branen (1993) dalam Suliantari (2009), mengungkapkan bahwa senyawa antimikroba selain bereaksi dengan membran sel yang berakibat pada peningkatan permeabilitas membran, kebocoran sel dan melisiskan dinding sel juga dapat menginaktifkan enzim-enzim intraseluler sehingga menggangu pembentukan dinding sel. 


\section{Kesimpulan}

Ekstrak kasar cacing tanah Pheretima sp. menyebakan perubahan morfologi terhadap sel bakteri Salmonella enteritidis. Perubahan terhadap sel bakteri berupa: terbentuk lubang pada permukaan sel bakteri, tonjolan-tonjolan pada permukaan sel bakteri, pengerutan sel bakteri, pemanjangan sel bakteri, dan terjadinya lisis sel bakteri, yang akan menyebabkan kematian sel bakteri. Konsentrasi ekstrak cacing tanah Pheretima sp. 10\% menimbulkan kerusakan yang lebih besar terhadap morfologi sel bakteri Salmonella enteritidis dibandingkan dengan konsentrasi 5\%. Selain itu, semakin lama waktu inkubasi dari kedua konsentrasi tersebut semakin besar pula kerusakan yang ditimbulkan. Namun konsentrasi ekstrak 5\% sudah merupakan konsentrasi yang optimum dalam menimbulkan kerusakan terhadap morfologi sel bakteri Salmonella enteritidis.

\section{Referensi}

Aydogdu, E, O, A., Aysin, C. (2008). Antibacterial and Hemolytic Activity of the Coelomic Fluid of Dendrobaena veneta (Oligochaeta, Lumbricidae) Living in Different Localities, 67 (1), 23 32.

Darkuni. (2001). Antimikroba, http://erickbio.wordpress.com/2011/07/03/anti-mikroba/ diakses pada tanggal 27 Oktober 2011.

Dudung. (2008). Berbiak $1.000 \mathrm{Kali}$ http://www.suaramerdeka.com. diakses pada tanggal 27 Oktober 2011.

Hasyim. (2011), Efektifitas Senyawa antimikroba dari Beberapa Cacing Tanah Lokal dan Bentuk Penghambata Terhadap Sel Bakteri Patogen, Program Studi Ilmu Pertanian Konsentrasi Peternakan, Pascasarjana, Universitas Hasanuddin, Makassar.

Mathur, A., Satish, K.V., Rakshanda, B., Santosh, K.S., Archana, P., G., Prasad, V., Dua, (2010). Antimicrobial Activity of Earthworm Extract, J. Chem. Pharm. Res, 2 (4), PP 51-57.

Miksusanti, Betty, S. L. J., Bambang, P., dan Gatot, T., (2008). Kerusakan Dinding Sel Escherechia coli K1. 1 oleh Minyak Atsiri Temu Kunci (Kaempferia pandurat), Jurnal Berita Biologi, 9 (1), 1-7.

Pelczar, M. J. \& E. C. S. Chan. (1986). Dasar-Dasar Mikrobiologi Jilid I, Terjemahan oleh Ratna Sri Hadiutomo dkk., Penerbit Balai Pustaka, Jakarta.

Rahmawati, (2010), Bioaktifitas Fraksi Protein Dari Cacing Tanah Pheretima sp. Sebagai Antibakteri Terhadap Staphylococcuu aureus Dan Salmonella typhi, Skripsi Jurusan Biologi, Fakultas Matematika Dan Ilmu Pengetahuan Alam, Universitas Hasanuddin.

Suliantari. (2009). Akvitas Antibakteri Dan MekanismePenghambatan Ekstrak Sirih Hijau (Piper betle Linn) Terhadap Bakteri Patogen Pangan, Sekolah Pascasarjana Institut Pertanian Bogor, Bogor.

Syahrurachman, A. (1994). Buku Ajar Mikrobiologi Kedokteran, ed revisi, Staf Pengajar Fakultas kedokteran universitas Indonesia, Jakarta. 
162 Jurnal Ilmiah Bionature, Volume 19 Nomor 2, Oktober 2018

Efek Ekstrak Kasar Cacing Tanah Pheretima sp. terhadap Morfologi Sel Bakteri

p-ISSN 1411 - 4720

Salmonella enteritidis

e-ISSN 2654 - 5160

(hlm. 152-162)

\begin{tabular}{|l|l|}
\hline Sahribulan & $\begin{array}{l}\text { Dosen Jurusan Biologi, Prodi Biologi, Jurusan Biologi, Fakultas } \\
\text { Matematika dan Ilmu Pengetahuan alam, Univeristas Negeri Makassar } \\
\text { E-mail: } \underline{\text { sahribulan24@gmail.com }}\end{array}$ \\
\hline Dirayah Rauf H & $\begin{array}{l}\text { Dosen Universitas Hasanuddin Makassar } \\
\text { E-mail: } \underline{\text { sahribulan24@gmail.com }}\end{array}$ \\
\hline Zohra Hasyim & $\begin{array}{l}\text { Dosen Universitas Hasanuddin Makassar } \\
\text { E-mail: } \underline{\text { sahribulan24@gmail.com }}\end{array}$ \\
\hline
\end{tabular}

